\title{
Grasslands of intermontane basins of Central Caucasus: land use legacies and present-day state
}

\author{
Elena Belonovskaya ${ }^{1, *}$, Raisa Gracheva ${ }^{1 \mathrm{a}}$, Ilya Shorkunov ${ }^{1 \mathrm{~b}}$ \& \\ Vera Vinogradova ${ }^{1 c}$
}

Keywords: buried soils, ecosystem convergence, land use history, mountain meadow-steppes, semi-natural grasslands, subalpine meadows.

Ključne besede: pokopana tla, zbliževanje ekosistemov, zgodovina rabe tal, gorski stepski travniki, polnaravna travišča, subalpinski travniki.
Received: 7. 12. 2015

Revision received: 4. 4. 2016

Accepted: 16. 4. 2016

Co-ordinating Editor: Orsolya Valkó

\begin{abstract}
Mountain semi-natural grasslands of intermontane basins of Central Caucasus, North Ossetia-Alania and the history of its land use were studied. It was found that post-forest, meadow-steppe and partially subalpine grasslands in the study area had been used as croplands for centuries and have been transformed into grazing lands about 60 years ago. In the last 20 years, the grasslands have been underused. It was revealed that current spatial distribution of grasslands is different from the classic scheme of natural climate-induced vegetation distribution. Species composition of meadow steppes is similar in different locations and does not reflect climatic differences of "dry" leeward and "wet" windward slopes of the intermontane basins. Present-day soils reflect parent material differences and erosion degree, but not topography-induced local climate specificity. However, discovered buried soils showed contrasting soil diversity on the southern and northern slopes. It is assumed that the present convergence of soil cover and vegetation is a result of long homogenising human impact and relatively short grassland development.
\end{abstract}

\section{Izvleček}

Opisali smo gorske polnaravne travnike v gorskih kotlinah srednjega Kavkaza, Republika Severna Osetija-Alanija, in zgodovino spremembe rabe tal. Ugotovili smo, da so nekdanje gozdne površine, stepske travnike in delno tudi subalpinske travnike, stoletja uporabljali kot obdelovalne površine in jih nato pred šestedestimi leti spremenili v pašnike. $\mathrm{V}$ zadnjih dvajsetih letih pa s travniki niso gospodarili ali pa so opuščeni. Ugotovili smo, da je trenutna prostorska razporeditev stepskih travnikov drugačna od klasične sheme razširjenosti vegetacije, ki so pod klimatskimi vplivi. Vrstna sestava stepskih travišč je podobna na različnih lokacijah in ne odraža klimatskih razlik med "suhimi” zavetrnimi in "vlažnimi" privetrnimi pobočji. Talne razmere odražajo razliko $\mathrm{v}$ matični podlagi in stopnji erozije, ne pa tudi posebnosti v klimi zaradi topografije. Vendar odkrita pokopana tla nakazujejo raznolikost tal na južnih in severnih pobočjih. Predvidevamo, da je današnja podobnost tal in vegetacije rezultat dolgotrajnega homogenzirajočega človekovega vpliva in relativno kratkotrajnega razvoja travišč.

\footnotetext{
1 Institute of Geography RAS, Staromonetny per. 29, 119017 Moscow, Russia. E-mail: belena53@mail.ru

* Corresponding author
} 


\section{Introduction}

Grasslands widely used as pastoral lands are the most valuable and multi-functional ecosystems in the rural mountain regions supporting wildlife, livestock and human livelihoods and creating specific upland environment. For millennia, varied types of mountain grasslands have been formed as semi-natural ecosystems under variations in natural development and land use. On a local and regional scale, the consequences of grazing on the grasslands are rather various. Thus in managed pastures as in the Alps, grazing can increase plant diversity, thereby increasing the positive influence on the number of ecosystem functions (Bötsch 2004, Hector \& Bagchi 2007). More commonly there are also evidences for the reduction of species richness and simplification of plant species composition of grasslands under grazing and pasture treatment in different regions (Kotlyakov \& Yashina 1987, O'Connor 2005, Suttie et al. 2005, Fischer et al. 2008, Allaby 2009, Bernhardt-Römermann et al. 2011, O'Connor et al. 2011 and others).

Transformation of land use including abandonment or underuse of pastoral lands is considered as the most significant factor for the changes of the grassland traits. Depending on the region, different responses of pastoral ecosystems to abandonment have been shown; in general, abandonment of extensively used areas often causes a decline in species and ecosystem diversity and a change of community composition (Tasser \& Tappeiner 2002, Maurer et al. 2006, Mayer et al. 2009, Schultz et al. 2011, Maccherini \& Santi 2012). However, there is a lack of data on long-term consequences of abandonment/underuse of the mountain grasslands, and some results supposedly reflect a succession stage (Tasser \& Tappeiner 2002). Besides, an impact of land-use history on the contemporary species composition, the structure of plant communities and the grassland ecosystem as a whole has to be taken into consideration (Lavorel et al. 2004, Fischer et al. 2008). This is especially important in the cases of conversion of arable lands into grasslands and when the researcher has exact information on the time span of grassland development.

In the North Caucasus, a mountain region with a long history of human use, high mountain ecosystems have been fundamentally transformed many times for human needs, first of all by forest devastation and widening the area of treeless landscapes for arable lands and grazing. Since the 1990s, socio-economic reforms have been causing population outflow from the mountains, and as a result, a sharp decrease in livestock numbers, underuse of pastures adjacent to populated areas and abandonment of remote grasslands were typical. This is especially the case in the Central Caucasus, Republic of North Ossetia-Alania (Gracheva \& Nefedova 2007, Gracheva et al. 2012).

How have pastoral ecosystems changed in response to land use change? The aim of our work was to study the state of mountain post-forest and subalpine grasslands and to reveal the history of land use and factors responsible for grasslands' contemporary traits.

\section{Materials And Methods}

\section{Study area}

Central Caucasus includes mountains of the North Caucasus located between Mount Elbrus in the West and Mount Kazbek in the East (Figure $1 \mathrm{~A}$ ). In this area, several sub-parallel ridges alternate with wide uplifted intermontane basins, which have been the main areas of population settlement and economic activity in the past millennia (Bliyev \& Bzarov 2000). Due to their location between mountainous barriers, slopes of intermontane basins have contrasting climatic conditions (Leontyev 1938, Vagin 2002). In the "rain shadow", on the leeward southern and eastern slopes, high temperatures and lack of moisture in summer and cold winters with thin snow

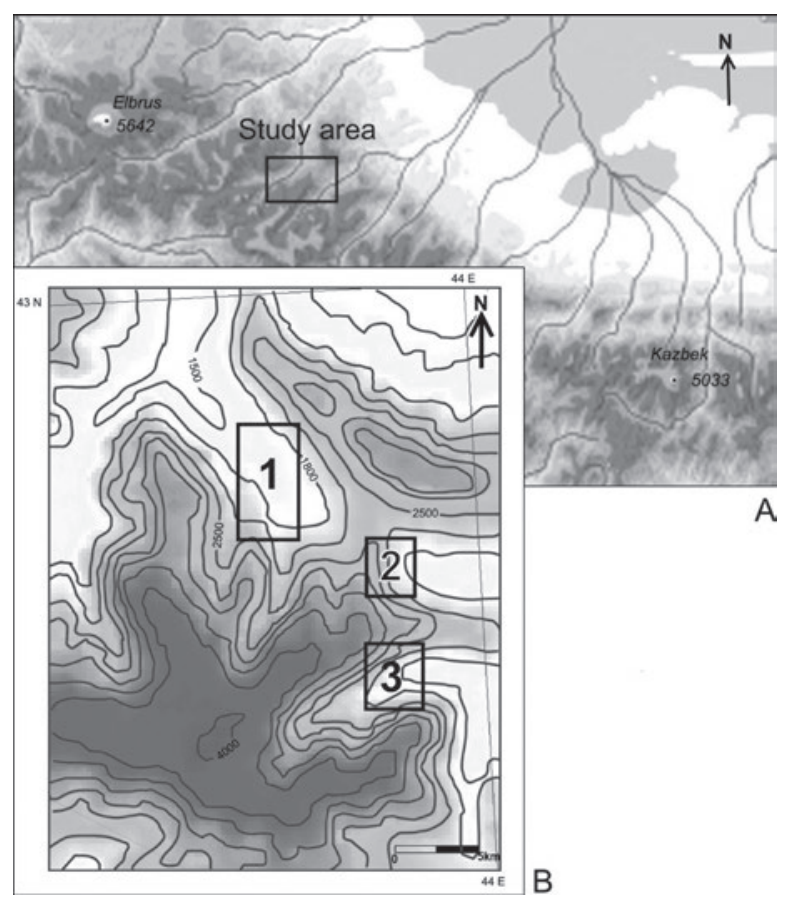

Figure 1: Location of the study area. A - location in the Central Caucasus; B - location of key study areas: 1 - Uallagkom Basin; 2 - Upper Zgid Basin; 3 - Tsey Basin.

Slika 1: Lokacija preučevanega območja. A - lokacija srednjega Kavkaza; B - lokacija ključnih preučevanih območij: 1 - Uallagkom; 2 - zgornji Zgid; 3 - Tsey. 
cover are characteristic. In natural environments, those conditions favour mountain steppe vegetation development. According to classic scientific reviews (Shiffers 1953) and our previous investigations (Belonovskaya 1995, Gracheva \& Belonovskaya 2010), meadow steppes, typical steppes and dry steppes are the main types of grasslands here. They belong to the Crimean-CaucasianWestern-Iranian group of mountain steppes, which relates mainly to the class Festuco-Brometea Br.-Bl. et Tx.1943.

In pristine natural conditions, meadow steppes are situated on the southern, southeastern and southwestern slopes at altitudes of $1,400-1,800(2,000) \mathrm{m}$ a.s.l. on Chernozem-like soils and Phaeozems. Plant communities are characterised by a total grass cover of $80-100 \%$ and a grass height of $60-80 \mathrm{~cm}$. The medium species diversity is high, more than 50 species per $100 \mathrm{~m}^{2}$. The character species are Stipa pennata, Stipa pulcherrima, Festuca valesiaca, Achillea millefolia, Salvia verticillata, Galium verum, Onobrychis petraea and some species of subalpine meadows: Alchemilla caucasica, Helictotrichon versicolor, Poa alpina, Phleum montanum, Amoria ambigua, Leontondon hispidus, Pedicularis sibthorpii, Polygala anatolica, Scabiosa caucasica, Centaurea fischeri etc. The zone of meadow-steppe grasslands can be considered as transition zone followed by subalpine meadows at higher altitudes.

Typical mountain steppes are spread on gentle and medium steep southern slopes at altitudes of 1,200-1,400 $(1,600) \mathrm{m}$ a.s.l.; main soils are Chernozems and Chernozem-like soils (Molchanov 2008). The total grass cover varies from 30 to $90 \%$ and the grass height from 40 to $60 \mathrm{~cm}$. The species diversity is slightly lower -30 species per $100 \mathrm{~m}^{2}$ - and mainly consists of bunch grasses like Stipa pennata, Stipa daghestanica, Festuca ovina, Bromopsis riparia, Bromus inermis, Koeleria gracilis and Phleum pratensis and sedges like Carex humilis etc.

Dry mountain steppes occupy the lower parts of the gentle and medium steep southern slopes at altitudes of 1,000-1,200 (1,400) m a.s.l.; soils are Leptic Chernozems and Kastanozems (Molchanov 2008). Plant communities have a sparse total grass cover (10-40\%), a low grass layer $(10-20 \mathrm{~cm})$ and a species diversity of not more than 20 species per $100 \mathrm{~m}^{2}$. Among the character species are Artemisia chamaemelifolia, Artemisia marschalliana, Thymus spp., Astragalus spp., Galium verum, Festuca ovina, Andropogon ischaemum, Elytrigia gracillima, Bromus inermis etc.

The well moistened windward northern and western slopes, more humid in the summer and snowy in winter, were formerly covered by mixed and coniferous forests and birch elfin woodlands on Distric or Eutric Cambisols (Vladychenski \& Dobrovolski 1998). Currently these slopes are covered by post-forest meadows and small patches of woodlands.
Grasslands at altitudes of $1,750-2,560 \mathrm{~m}$ a.s.l. were studied in the wide intermontane basin between Bokovoi Ridge (Side Ridge) and Skalistyi Ridge (Rocky Ridge) in North Ossetia-Alania (Figure 1B). Three key areas were studied: the Uallagkom Basin located in the Iraf district and the basins of Tsey and Upper Zgid in the Alagir district.

\section{Methods}

Interdisciplinary research was aimed to provide integrated insights into factors and processes of current formation and change of ecosystems of intermontane basins.

Field geobotanical and soil research was carried out in the key areas in 2014/2015; data obtained in 2010 were also used. Homogeneous grassland plots of $100 \mathrm{~m}^{2}$ size were sampled at different altitudes on slopes with various aspects and inclinations as well as several plots of birch elfin woods on the northern and pine forests on the southern slopes. The record of each plot includes general, topographic and other data such as altitude, slope aspect and inclination, total vegetation cover and a list of vascular plants and their coverages according to the old Braun-Blanquet scale (Braun-Blanquet 1964). 40 phytosociological relevés of the plots were collected and stored in the TURBOVEG database management program (Hennekens \& Schaminée 2001). Numerical classification of the data set was performed by the TWINSPAN algorithm (Hill 1979) in the JUICE program (Tichý 2002). Nomenclature follows the checklist of Cherepanov (1995). The scatter diagrams of spatial distribution peculiarities of plots for each group of relevés were constructed using accessible approaches within Microsoft Excel. 22 plots having exact data of arable land conversion into grassland were studied. Soils of all plots were described morphologically using Munsell Soil Colour Charts, field detecting the presence of carbonates and soil effervescence class assessment (using $1 \mathrm{M} \mathrm{HCl}$ ). In addition, 18 soil profiles were sampled. Soil analyses were made in the laboratory of the Department of Soil Genesis and Evolution (Institute of Geography, RAS) by recommended routine methods (IUSS Working Group 2014). Soils were named following the WRB soil classification system (IUSS Working Group 2014).

Historical evidences and official data were studied for revealing sequences of land use changes and approximate time spans of certain management regimes. Statistical data on demographic changes and changes in animal husbandry in the study areas were gathered and analysed for assessment of current changes in human impact on mountain grasslands. As sources of information, state censuses, archive data from the Iraf and Alagir districts and household record books of the rural settlements of 
the study areas were used. For revealing the land use history of each studied plot, informal interviews of the villagers and rural administrations were made. Methods and some results of demographic and land use study have been published (Gracheva et al. 2012).

\section{Results}

\section{Land use history: brief overview}

The intermontane basins of North Ossetia-Alania are areas of ancient human settlement. They have been repeatedly abandoned and re-populated during at least the last three thousand years (Kovalevskaya 1984). Population density and land use intensity were especially high during the last 500-600 years after the population exodus from the lowland. By the middle of the 19th century, more than half of the population of North Ossetia lived in the mountains (Bliyev and Bzarov 2000). In the 16th and 17 th centuries, intermontane basins were the main areas of cropland in Alania producing barley, rye and oats, while lowlands were used mainly for animal husbandry. It is considered that large-scale plowing of the steppes and deforestation of the northern slopes to create arable land and grazing areas began much before (Kaloyev 1981, 1993). By the end of 19th century, mountainous post-forest and steppe areas had long been used as arable lands (Gaibov 1905, Miller 1887). Permanent adaptation of the environment to create grazing and arable land, deforestation, slope terracing and long agricultural use have transformed the natural landscapes of intermontane basins into agro-landscapes and changed the natural spatial distribution of vegetation and soils.

The reduction of arable lands began in the 1920s following the mountain population outflow. According to the census of 1926, the mountain population was 20,500 people or $7.5 \%$ of the total population of North Ossetia within the present borders (Gracheva et al. 2012). Total abandonment of croplands occurred in the 1950s following a policy of increasing mountain animal husbandry. Plowed fields were converted into grazing lands including terraced slopes. For example, in rural settlements of the Uallagcom basin, Iraf district, arable lands occupied about 1000 ha in 1910, 200 ha in 1960 and 15 ha in 2014 (archive data and land records of the Iraf district, North Ossetia-Alania).

In general it can be concluded that the present postforest and meadow-steppe grasslands of intermontane basins of the Central Caucasus have been used as arable land for centuries; only from the 1950s, they were developed as grasslands and served as pastures.
In the 1990s, there was a new wave of mountain population outflow. The present mountain population is less than $1 \%$ of the population of North Ossetia-Alania, which is 706000 people (Regiony Rossii 2015). The demise of planned economy has led to a significant reduction of livestock. Small cattle practically disappeared from the mountains, and thus the factor with the largest impact on the grasslands was excluded (Figure 2).

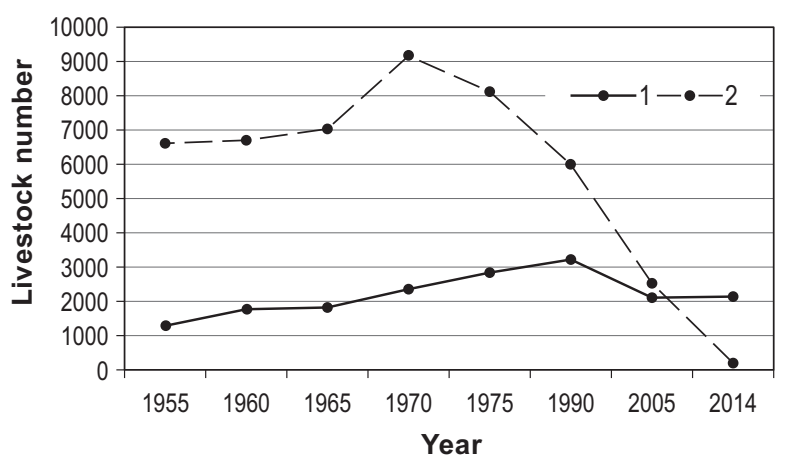

Figure 2: Mountain livestock dynamics in the Iraf district, North Ossetia-Alania: 1 - cattle; 2 - small cattle.

Slika 2: Dinamika živine v gorah okrožja Iraf, Severna Osetija-Alanija: 1 - govedo; 2 - majhno govedo.

New land use transformation is reflected in underuse and abandonment of grasslands. In the last two decades, former agro-ecosystems of the area have been mainly developing under the influence of natural processes.

\section{Vegetation of intermontane basins: Case studies}

Three main groups of plant communities were distinguished in the study area using the frequency and constancy concept (Table 1).

The subalpine birch elfin woods (group 'w') are situated on the very steep northern and eastern slopes at altitudes of $1885-2120 \mathrm{~m}$ a.s.l. They are characterised by forest species such as Betula pubescens, Sorbus aucuparia, Salix caprea, Galium boreale, Viola canina, Fragaria vesca and Vaccinium vitis-idaea and also species that could be met on the post-forest or forest-edge and subalpine meadows: Primula ruprechtii, Primula macrocalyx, Cruciata laevigata, Calamagrostis arundinacea, Agrostis tenuis, Avenella flexuosa, Brachypodium sylvaticum, Inula orientalis, Stachys macrantha, Anthoxanthum odoratum, Carum carvi, Luzula multiflora, Gentiana cruciata and Amoria montana. One releve of the pine forest on the steep southern slope with the same species also belongs to this group (Figure 3). Woodlands are developed usually on Leptic Cambisols (shallow Brown forest soils). 


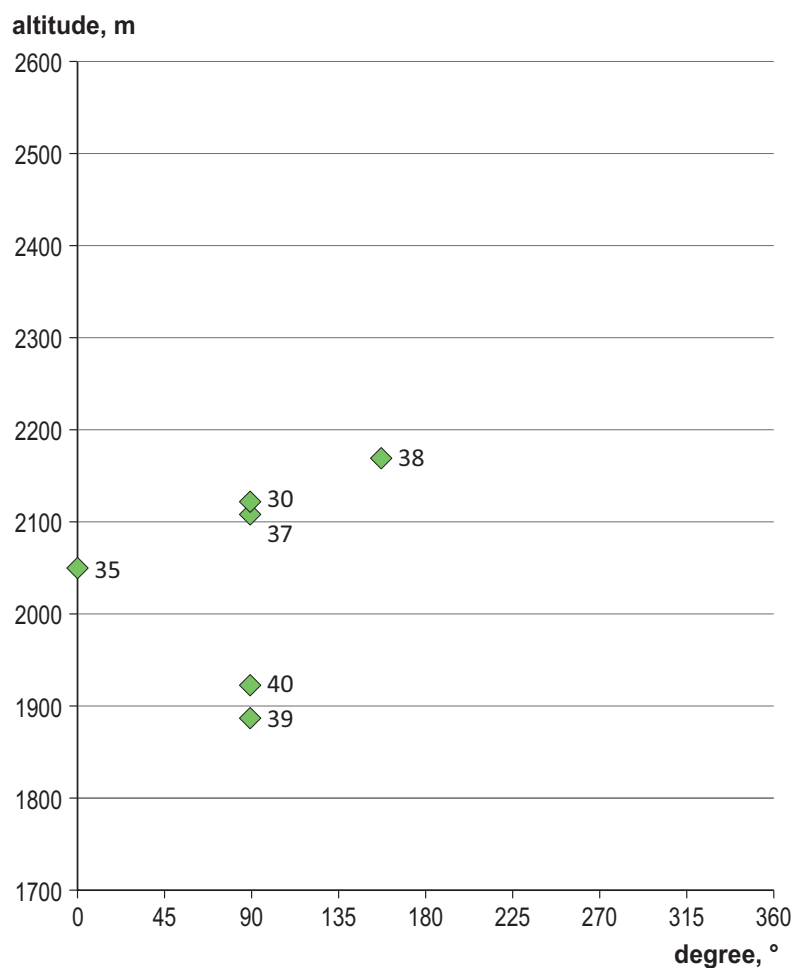

Figure 3: Spatial distribution of wood communities within the intermontane basins of the key areas. Legend: Numbers correspond to the relevé numbers in Table 1 ; $\mathrm{y}$-coordinate - altitudes a.s.l. (m); $\mathrm{x}$ coordinate - slope aspect (degree): $0^{\circ}-\mathrm{N}, 45^{\circ}-\mathrm{NE}, 90^{\circ}-\mathrm{E}, 135^{\circ}-\mathrm{SE}$, $180^{\circ}$ - S, $225^{\circ}$ - SW, $270^{\circ}$ - W, $315^{\circ}$ - NW.

Slika 3: Prostorska razporeditev lesnatih združb v visokogorskih kotlinah na ključnih območjih. Legenda: številke se nanašajo na številke popisov v Tabeli 1 ; $y$-koordinata - višina n.m.v. (m); x-koordinata nagib (degree): $0^{\circ}-\mathrm{S}, 45^{\circ}-\mathrm{SV}, 90^{\circ}-\mathrm{V}, 135^{\circ}-\mathrm{JV}, 180^{\circ}-\mathrm{J}, 225^{\circ}-\mathrm{JZ}$, $270^{\circ}-\mathrm{Z}, 315^{\circ}-\mathrm{SZ}$.

In subalpine meadow communities (group “m”) on moderately steep slopes of various expositions at altitudes from 1820 to $2560 \mathrm{~m}$ a.s.l. (Figure 4), Bromopsis variegata, Anthoxanthum odoratum, Scabiosa caucasica and Astrantia maxima dominate, together with the great diversity of other species typical for the high mountain meadows of the Caucasus: Anthemis sosnovskyana, Poa alpina, Festuca ovina, Alchemilla caucasica, Ranunculus oreophyllus, Veronica gentianoides, Myosotis alpestris, Festuca valesiaca, Phleum montanum, Alchillea millefolium, Galium verum, Helictotrichon versicolor, Potentilla crantzii, Amoria ambigua, Leontondon hispidus, Trifolium canescens, Pedicularis sibthorpii, Polygala anatolica, Bupleurum polyphyllum, Silene ruprechtii, Pulsatilla albana, Centaurea fischeri, Lotus corniculatus, Plantago medium, Plantago atrata, Campanula hohenackeri, Scabiosa bipinnata, Seseli libanotis, Trifolium medium, Amoria montana, Dactylorhiza spp., Vicia alpinum, Veronica chamaedrys, Gentiana cruciata and Scabiosa caucasica.

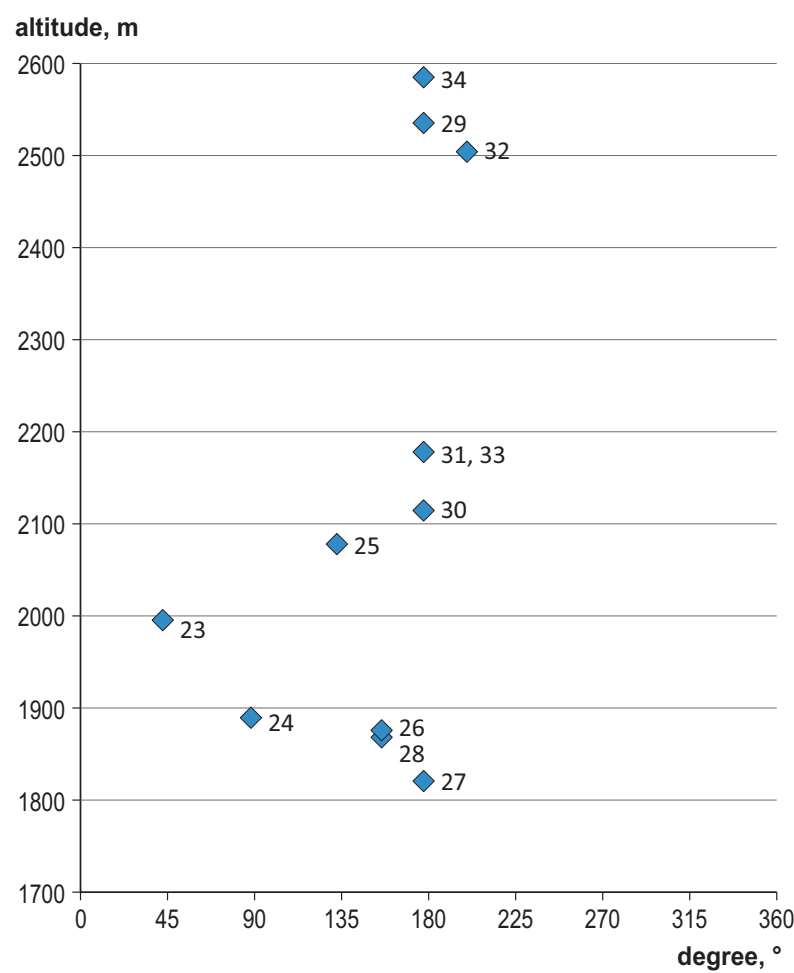

Figure 4: Spatial distribution of subalpine meadows within the intermontane basins of the key areas. Legend: see Figure 3.

Slika 4: Prostorska razširjenost subalpinskih travišč v visokogorskih kotlinah na ključnih območjih. Legenda: glej Sliko 3.

The group of meadow-steppe communities (group "s") occupies the slopes of various expositions at altitudes of 1,760-1,980 $\mathrm{m}$ a.s.l. (Figure 5). They include, besides the species of the Caucasian subalpine meadows, species of the mountain meadow steppes: Salvia verticillata, Aster alpinus, Medicago furcata, Pentaphylloides fruticosa, Onobrychis petraea, Thymus collinus, Bromopsis riparia, Artemisia chamaemelifolia, Artemisia marschalliana, Astragalus oreades, Veronica caucasica, Carex humilis, Linum nervosum, Koeleria cristata, Anthyllis variegata, Tephroseris caucasigena, Artemisia splendens, Stipa pulcherrima and Linum hypericifolia.

The difference in species composition between grassland groups is not significant. Approximately 2/3 of plant species of these two groups are common. An altitudinal change of meadow-steppe communities by subalpine meadows is observed only on southern slopes. The most interesting is that climatic differences of slope aspect, especially in humidity, are not reflected in the current spatial distribution of these grasslands types. Meadow steppes cover former arable lands on abandoned terraces and underused pastures both on leeward and windward mountain slopes. 


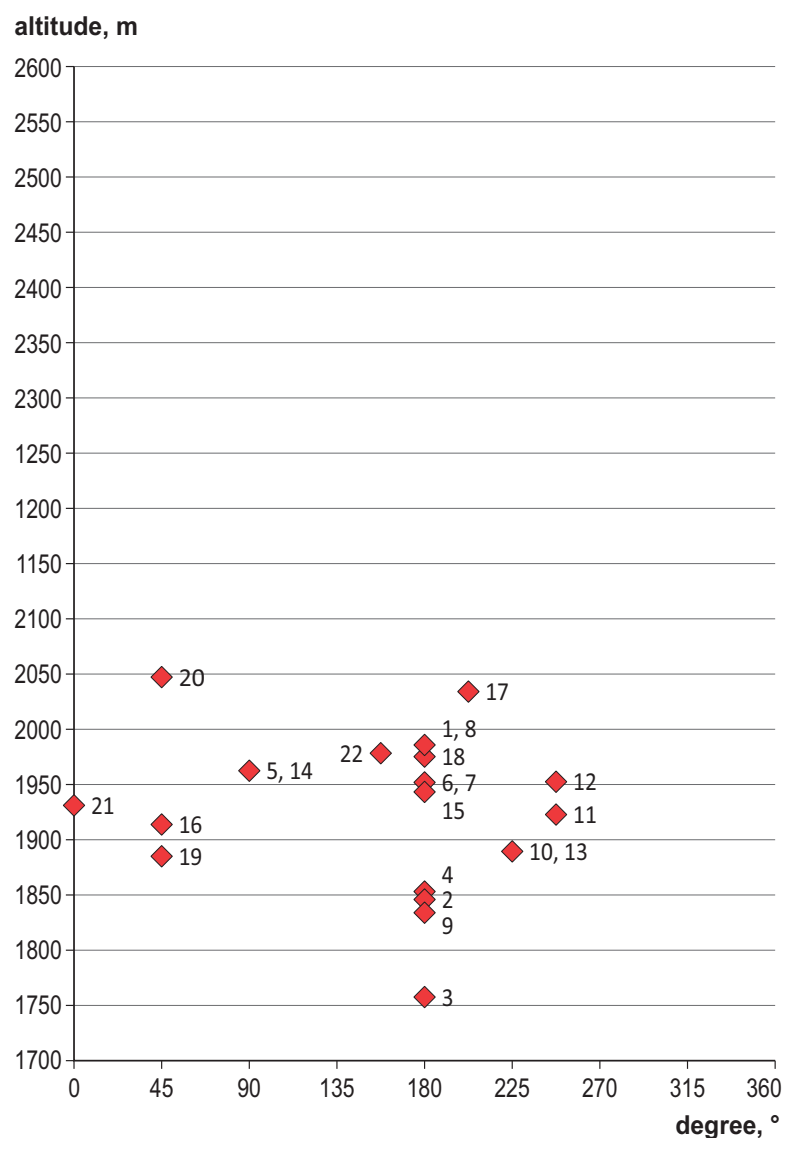

Figure 5: Spatial distribution of meadow-steppe communities within the intermontane basins of the key areas. Legend: see Figure 3. Slika 5: Prostorska razširjenost stepskih travniških združb v visokogorskih kotlinah na ključnih območjih. Legenda: glej Sliko 3.

The convergence of plant communities is in contradiction with different conditions of temperature and humidity of opposite mountain slopes. Taking into account 1 ) the relatively short duration of the post-arable phase (about 60 years) and 2) 15-20 years of underuse/ abandonment, present-day grassland plant communities can be considered as early stages of development. Soil studies confirm this assumption.

\section{Soils of grasslands as sources of information}

As mentioned above, in natural environments of the Central Caucasus, Chernozems and Paheozems are characteristic for steppe and meadow steppe leeward slopes and Cambisols for forested downwind slopes. In the study area, soils of post-arable grasslands of leeward and windward slopes have very similar properties such as a thin humus horizon of not more than $5-7 \mathrm{~cm}$ with grey-brown color (10YR 4/2 according Munsell Color Chards), a degraded soil structure, stone absence in the topsoil and sometimes remains of old arable horizons and traces of tillage pan. These properties are evidence of stone removal, continuous plowing and soil erosion.

Soils of supposed Chernozem locations are usually carbonate-rich and have high base saturation, but they lack the characteristic feature of a Chernozem, i. e. the topsoil chernic horizon with its blackish color, well-developed granular or fine subangular blocky soil structure and thickness of more than $25 \mathrm{~cm}$ (IUSS Working Group 2014). However, buried horizons with chernic properties (2,5Y 3/1 according to Munsell Color Chards, well structured, thickness more than $30 \mathrm{~cm}$ and rich of carbonate) were found in 10 soil profiles of 16 studied in the grasslands of the "dry" southern and southeastern slopes (Figure 6). In the soils of grasslands of the "wet" northern and northwestern slopes we identified traces of buried soils, which were assumed to be Cambisols in 6 profiles of 12 .

Present-day soils of opposite slopes with different conditions have no clear contrasts; the difference depends on the parent rock and the degree of erosion. Contrasting buried soils can be explained only by former climateinduced soil diversity developed before intense and long agricultural land use, which had a homogenising effect on soils. Radiocarbon dating of buried soils is supposed to give more information on the pre-agricultural period.

Thus our soil research confirmed historical data on wide spreading of arable lands in the past and revealed convergence of the present soil cover as compared to the former one. We can assume that soil convergence may support convergence of vegetation cover. However, another possible assumption is that post-agricultural ecosystems are at the early stages of their development as compared to longlived grasslands and had not enough time for adaptation to different environments.

\section{Discussion}

Examples from different regions underpin the significance of management for the diversity of ecosystems and the richness of the biota, and land use is considered to be the most significant factor for the changes of grassland traits. The case of the Central Caucasus, North Ossetia-Alania, confirms that (Körner et al. 2004). The simplest scheme of land use change during multi-century colonisation developed in the course of our research includes forest devastation and removal of woody plants, terracing, plowing during several centuries, conversion of arable lands into grasslands (about 60 years ago), permanent grazing and abandonment/underuse of grazing lands about 20 years 
Figure 6: Soil profile with buried Chernozem-like soil developed on the southern slope, 1930 m a.s.l. Meadow steppe, former cropland. North OssetiaAlania, Iraf district, Uallagkom Basin. Scale spacing $10 \mathrm{~cm}$. Photo I. G. Shorkunov.

Slika 6: Talni profil pokopanih černozemu podobnih tal, razvitih na južnem pobočju, 1930 m n.m.v. Stepski travnik, nekdanja obdelana površina, Severna Osetija-Alanija, okrožje Iraf, kotlina Uallagkom. Merilo $10 \mathrm{~cm}$. Foto I. G. Shorkunov.

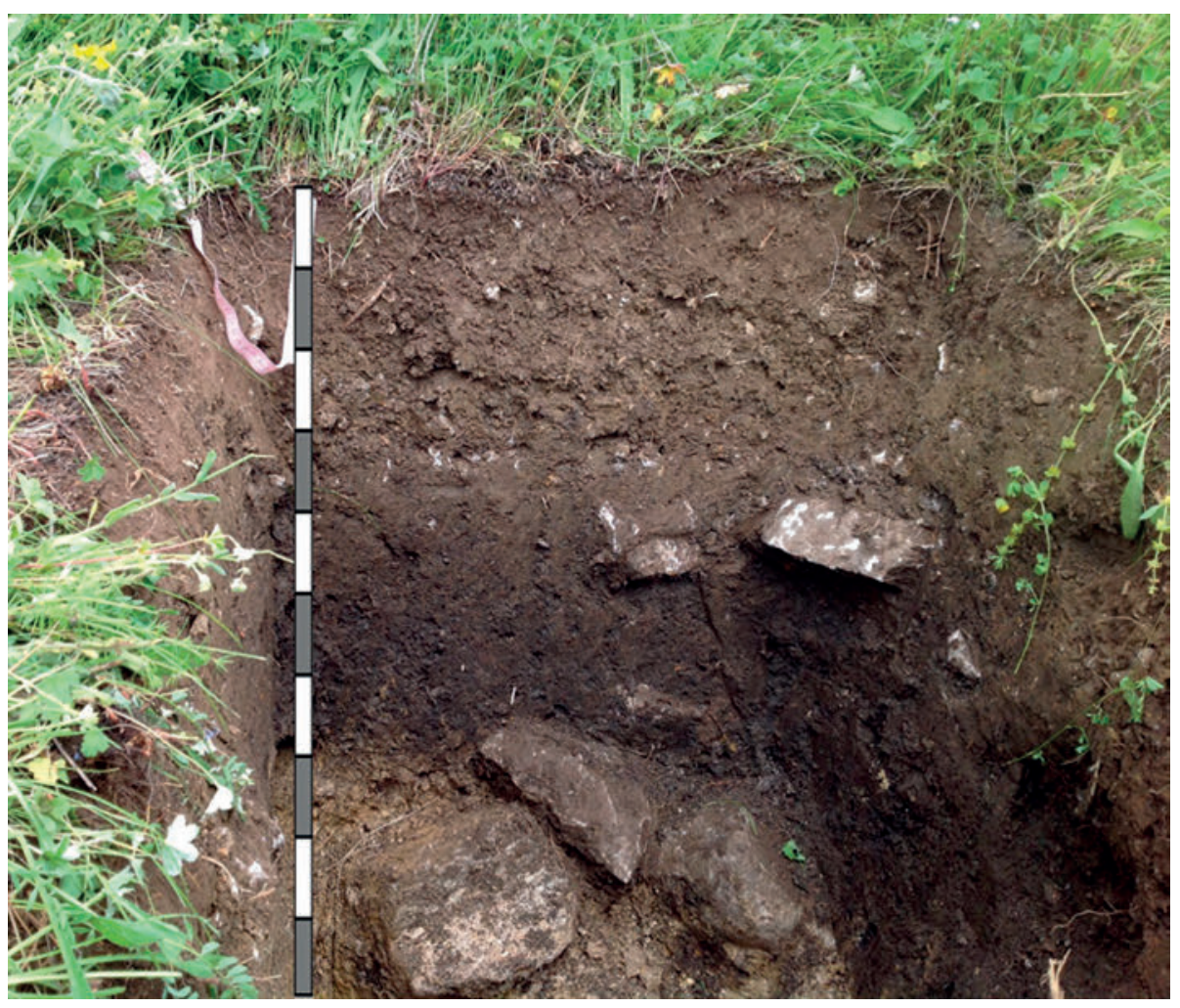

ago. The most unexpected finding was the convergence of plant communities independent of location differences. Species composition follows the altitudinal change to some degree, but does not reflect the humidity difference of different slope aspects.

What processes are responsible for grassland ecosystem convergence? In the first approximation, there can be several explanations.

It is known that the type of vegetation indicates the time passed since abandonment (Tasser \& Tappeiner 2002). The grasslands of the study area were formed as grasslands about 60 years ago after a long regime of plowing and amelioration of the croplands. Post-agricultural ecosystems are at the early stages of their development as compared to long-lived pastures.

Subsequent permanent grazing for about 40 years could suppress the course of natural succession; reduction of grazing or abandonment and especially exclusion of sheep from the livestock can give way to natural processes. There are a number of indications that abandonment of extensively used areas often causes a decline in species and ecosystem diversity (Maccherini \& Santi 2012, Maurer et al. 2006, Mayer et al. 2009, Schultz et al. 2011, Sebastia et al. 2008).

The informative role of soils is extremely important considering the fact of grassland convergence. The discovery of buried soils with different properties, which are evidence of contrasting environment conditions in the past, confirms the concept of soil cover convergence as a result of long agricultural use. It could be assumed that the similar species composition of subsequent pastoral ecosystems reflected soil similarity. On the other hand, present-day similarity of plant communities can be considered as cumulative effect of land use changes: long-term existence of croplands, subsequent establishment of vegetation and grazing and finally reduction of grazing or abandonment.

There are many arguments for the assumption that changes in land use will have a stronger impact on the state of grasslands than climate change (Aguiar 2005, Lüscher et al. 2005, Bernhardt-Römermann et al. 2011). However, the full effect of climate change is not yet understood, and current responses of the mountain vegetation to climate change are not clearly defined in spite of much attention given to the subject (Becker \& Bugmann 2001, Beniston 2003, Akatov 2009, White et al. 2011). Climate-induced consequences are likely to be highly site-specific including possible indirect consequences of climate change (Cowles et al. 2016).

The analysis of climate changes made for the Central Caucasus and the study area shows normal humidification of the study area in the years 2000-2006. In the years 2007-2013, which were dry in most parts of the 
south of European Russia, humidity increased in the middle mountains of Central Caucasus including the studied area. In the period 1981-2010, the sum of air active temperatures was increased by $100-150{ }^{\circ} \mathrm{C}$ compared to the period 1951-1980 in the same area (Vinogradova et al. 2015). Thus the trend of climate change during the last decades may have improved the conditions for vegetation growth and productivity.

\section{Acknowledgements}

Researches were supported by RFBR grant № 14-05 00233A. The authors are very grateful to Dr. Aiko Huckauf for the linguistic edition and to Dr. Orsolya Valkó for the comments and general edition of the text.

\section{References}

Aguiar, M. B. 2005: Biodiversity in grasslands: current changes and scenarios for the future. In: Reynolds, S. G. \& Frame, J. (eds.): Grasslands: Developments Opportunities Perspectives. FAO and Science Publishers, Roma and Plymouth, pp. 261-280.

Akatov, P. V. 2009: Changes in the upper limits of tree species distribution in the Western Caucasus (Belaya River basin) related to recent climate warming. Russian Journal of Ecology 40(1): 33-38.

Allaby, M. 2009: Grasslands. Biomes of the Earth Series. Infobase Publishing, 270 pp.

Becker, A. \& Bugmann, H. (eds.) 2001: Global Change and Mountain Regions: The Mountain Research Initiative. IGBP Report Series 49; GTOS 28; IHDP Report Series 13. Stockholm.

Belonovskaya, E. A. 1995: The Human-induced Transformation of the Ecosystems of the Caucasus Mountains. In: Breymeyer, A. (ed.): Euro-MAB IV. Conference Mountain Zonality Facing Global Change. Conference papers, 21. Institute Geografii i prestrezennego Zagospodarowania, Polska Academia nauk, Warszawa, 42-57.

Beniston, M. 2003: Climatic change in mountain regions: a review of possible impacts. Climate Change 59: 5-31.

Bernhardt-Römermann, M., Römermann, C., Sperlich, S. \& Schmidt, W. 2011: Explaining grassland biomass - the contribution of climate, species and functional diversity depends on fertilization and mowing frequency. Journal of Applied Ecology 48: 1088-1097.

Bliyev, M. M. \& Bzarov, R. S. 2000: Istoriya Osetii s drevneishikh vremen do kontsa XIX veka. History of Ossetia from ancient time to the end of XIX century. Ir Publishing, Vladikavkaz, $354 \mathrm{pp}$.

Bötsch, M. 2004: Swiss agricultural policy and its focus on grassland. In: Lüscher, A., Jeangros, B., Huguenin, O., Lobsiger, M., Millar, N. \& Suter, D. (eds): Land Use Systems in Grassland Dominated Regions. Proceedings of the 20th General Meeting of the European Grassland Federation Luzern, Switzerland 21-24 June 2004, pp. 5-10.

Braun-Blanquet, J. 1964: Pflanzensoziologie. Grundzüge der Vegetationskunde. 3rd ed. Springer, Wien 865 pp.
Cherepanov, S. K. 1995: Plantae Vasculares Rossicae et Civitatum Collimitanearum (in Limicis URSS olim). "Mir i Semia - 95", S.Petropolis, $990 \mathrm{pp}$.

Cowles, J. M., Wragg, P. D., Wright, A. J., Powers, J. S. \& Tilman, D. 2016: Shifting grassland plant community structure drives positive interactive effects of warming and diversity on aboveground net primary productivity. Global Change Biology 22(2): 741-749.

Fischer, M., Rudmann-Maurer, K., Weyand, A. \& Stöcklin, J. 2008: Agricultural Land Use and Biodiversity in the Alps. How Cultural Tradition and Socioeconomically Motivated Changes Are Shaping Grassland Biodiversity in the Swiss Alps. Mountain Research and Development 28(2):148-155.

Gaibov, N. D. 1905. O pozemel'nom ustroistve gorskih plemen Terskoi oblasti. Istoricheskii ocherk. Tipografia Okruzhnogo Shtaba Kavkazskogo Voennogo Okruga, Tiflis, 195 pp.

Gracheva, R. G., \& Belonovskaya, E. A. 2010: Sostoyanie pastbishnykh ecosystem Tsentralnogo Kavkaza pod vozdeistviem sovremennogo gornogo zhivotnovodstva. Izvestiya RAN, seriya geograficheskaya 1: 90-103.

Gracheva, R., Kohler, Th., Stadelbauer, J. \& Meessen, H. 2012: Population dynamics, changes in land management, and the future of mountain areas in the Northern Caucasus: The example of North Ossetia. Erdkunde 66(3): 197-219.

Gracheva, R. G. \& Nefedova, T. G. 2007: Gornye poseleniya Severnoy Osetii: sovremennoye sostoyaniye i vozmozhnyye perspektivy razvitiya. Izvestiya RAN, seriya geograficheskaya 5: 7-16.

Hector, A. \& Bagchi, R. 2007: Biodiversity and ecosystem multifunctionality. Nature 448: 188-190.

Hennekens, S. M. \& Schaminée, J. H. J. 2001: TURBOVEG a comprehensive data base management system for vegetation data. Journal of Vegetation Science 12: 589-591.

Hill, M. O. 1979: DECORANA and TWINSPAN for ordination and classification of multivariate species data: a new edition, together with supporting programs. FORTRAN 77. Institute of Terrestrial Ecology, Huntingdon.

IUSS Working Group WRB. 2014: World Reference Base for Soil Resources 2014. World Soil Resources Reports No. 106. FAO, Rome.

Kaloyev, B. A. 1981: Zemledelie narodov Severnogo Kavkaza. Nauka, Moskva, 249 pp.

Kaloyev, B. A. 1993: Skotovodstvo narodov Severnogo Kavkaza (s drevneyshikh vremen do nachala XX veka). Nauka, Moskva, 231 pp.

Körner, Ch., Spehn, E. M. \& Nakhutsrishvili, G. 2004: Grazing the highlands: food, biodiversity and catchment implications. In: Lúscher, A., Jeangros, B., Kessler, W., Huguenin, O., Lobsiger, M., Millar, N. \& Suter, D. (eds.): Land use systems in grassland dominated regions. Proceedings of the 20th General Meeting of the European Grassland Federation, Luzern, Switzerland, 21-24 June 2004, pp. 278-280.

Kotlyakov, V. M. \& Yashina, A. V. 1987: Transformatsiya gornykh ekosistem bolshogo Kavkaza pod vliyaniem khozyaystvennoy deyatelnosti. Akademiya nauk SSSR, In-t geografii, 160 pp.

Kovalevskaya, V. B. 1984: Kavkaz i Alany. Nauka, Moskva, 192 pp.

Lavorel, S., Quétier, F., Gaucherand, S., Choler, P., Clément, G. \& Bornard, A. 2004: Past and present land use effects on subalpine grassland species and functional diversity. In: Lúscher, A., Jeangros, B., 
Kessler, W., Huguenin, O., Lobsiger, M., Millar, N. \& Suter, D. (eds.): Land use systems in grassland dominated regions. Proceedings of the 20th General Meeting of the European Grassland Federation, Luzern, Switzerland, 21-24 June 2004, pp. 287-289.

Leontyev, G. S. 1938: "Dozhdevye teni” za Skalistym hrebtom Central'nogo Kavkaza. Izvestiya GGO 70 (2): 272-279.

Lüscher, A., Fuhrer, J. and Newton, P. C. D. 2005: Global atmospheric change and its effect on managing grassland systems. In: McGilloway, D. A. (ed.): Grassland: A Global Resource. Wageningen Academic Pub, 2005, pp. 251-264.

Maccherini, S. \& Santi, S. 2012: Long-term experimental restoration in a calcareous grassland: Identifying the most effective restoration strategies. Biological Conservation 146(1): 123-135.

Maurer, K., Weyand, A., Fischer, M. \& Stöcklin, J. 2006: Old cultural traditions, in addition to land use and topography, are shaping plant diversity of grasslands in the Alps. Biological Conservation 130: 438-446.

Mayer, R., Kaufmann, R., Vorhauser, K. \& Erschbamer, B. 2009: Effects of grazing exclusion on species composition in high-altitude grasslands of the Central Alps. Basic and Applied Ecology 10(5): $447-455$.

Miller, V. F. 1887: Osetinskie etyudy. Uchenye zapiski imperatorskogo Moskovskogo universiteta. V. III. Moskva, 226 pp.

Molchanov, E. N. 2008: Mountainous meadow chernozem-like soils of high mountains in the North Caucasus region. Eurasian Soil Science December 2008, 41(12), pp. 1268-1281.

O'Connor, T. G. 2005: Influence of Land Use on Plant Community Composition and Diversity in Highland Sourveld Grassland in the Southern Drakensberg, South Africa. Journal of Applied Ecology 42 (5): 975-988.

O'Connor, T. G., Greg Martindale, G., Craig D. Morris, C. D., Alan Short, A., Witkowski, E. T. F. \& Scott-Shaw, R. 2011: Influence of Grazing Management on Plant Diversity of Highland Sourveld Grassland, KwaZulu-Natal, South Africa. Rangeland Ecology \& Management 64(2): 196-207.

Regiony Rossii 2015. Sotsial'no-ekonomicheskie pokazateli. Rosstat, Moskva, 1266 pp.

Schultz, N. L., Morgan, J. W. \& Lunt, I. D. 2011: Effects of grazing exclusion on plant species richness and phytomass accumulation vary across a regional productivity gradient. Journal of Vegetation Science 22: $130-142$.

Sebastia, M. T., de Bello, F., Puig, L. \& Taull, M. 2008: Grazing as a factor structuring grasslands in the Pyrenees. Applied Vegetation Science 11: 215-223.

Shiffers, E. V. 1953: Rastitel'nost Severnogo Kavkaza i Ego Prirodnye Kormovye Ugod'ya. Izdatel'stvo AN SSSR, Moskva-Leningrad, 400 pp.

Suttie, J.M., Reynolds, S.G. \& Batello, C. 2005: Grassland of the world. FAO Rome. http://www.fao.org/docrep/008/y8344e/y8344e05. htm\#TopOfPage.

Tasser, E. \& Tappeiner, U. 2002: Impact of land use changes on mountain vegetation. Applied Vegetation Science 5(2): 173-184.

Tichy, L. 2002: JUICE, software for vegetation classification. Journal of Vegetation Science 13: 451-453.
Vagin, V. S. (ed.) 2002: Klimat. Prirodnye resursy Respubliki Severnaya Osetia-Alania. Vladikavkaz, Proekt-Press, 224 pp.

Vinogradova, V. V., Titkova, T. B., Belonovskaya, E. A. \& Gracheva, R. G. 2015: Vozdeistvie izmeneniya klimata na gornye landshafty Severnogo Kavkaza (The impact of climate change on mountain landscapes of the North Caucasus). Sovremennye problemy distantsionnogo zondirovaniya Zemli iz kosmosa 12(6): 35-47.

Vladychenski, A. S. \& Dobrovolski, G. V. 1998: Osobennosti Gornogo Pochvoobrazovania. Moskva, Nauka, 189 pp.

White, Sh. R., Carlyle, C. N., Fraser, L. H. \& Cahil, J. F. 2011: Climate change experiments in temperate grasslands: synthesis and future directions. Biology Letters 8: 484-487.

\section{Appendix}

Field characteristics of the relevés and coverage of the layers in Table 1 given in the following order: locality, date, relevé number, tree layer (\%), shrub layer (\%), herb layer $(\%)$, altitude (m), aspect, inclination (\%).

Iraf district, Uallagkom basin. The Dargonkom River valley, the right bank, 08.06.2010: 2) -; -; 55; 1846; S; 17 - 5) -; -; 60; 1962; E; 27 -14) -; -; 80; 1962; E; 5. 10.06.2010: 1) -; -; 70; 1957; S; 20 - 6) -; -; 95; 1952; S; 2 - 8) -; -; 50; 1985; S; 15. The Dargonkom River valley, the left bank, 08.06.2010: 21) -; -; 80; 1931; N; 20 - 39) -; -; 60; 50; 1885; N; 12. - 10.06.2010; 19) -; -; 85; 1884; NE; 10. - 28.06.2014: 17) -; -; 80; 2034; SSW, 15 - 18) -; -; 40; 1975; S; 25. The Songutidon River valley, the left bank, 27.06.2014: 20) -; -; 100; 2047; NE, 30 - 23) -; -; 90; 1996; NE; 5 - 35) 50; -; 50; 2047; N; 30 -40) 60; 5; 70; 1919; N; 15. The Songutidon River valley, the right bank, 11.06.2010: 3) -; -; 85; 1758; S; 20. The Komidon River valley, the right bank, 09.06.2010: 15) -; -; 65;1943; S; 15 - 16) -; -; 75; 1914; NE; 25. 10.06.2010: 4) -; -; 45; 1854; S; 25. - 25.06.2014: 9) -; -; 30; 1834; S; 35. - 26.06.2014: 10) -; -; 00; 1890; SW; 30 - 11) -; -; 80; 1923; SWW; 5 - 12) -; -; 75; 1952; SWW; 10 - 13) -; -; 65;1890; SW; 35 - 24) -; -; 100; 1890; N; 15.

Alagir district, the Tseydon-river valley, the left board, 20.06.2014: 22) - -; -; 75; 1976; SSE; 30 - 25) -; -; 85; 2078; SE; 25. - 22.06.2014: 26) -; -; 80; 1878; SSE; 25 - 27) -; -; 50; 1821; S; 25 - 28) -; -; 95; 1869; SSE; 15. -23.06.2014: 34) -; -; 60; 2585; S; 30 - 38) 40; 20; 30; 2168; SE; 25.

Alagir district, Upper Zgid basin, Upper Zgid village vicinities, 07.08.2015: 32) -; -; 80; 2505; SSE; 10. 08.08.2015: 29) -; -; 100; 2536; S; 5 - 30) -; -; 85; 2116; S; 10 - 31) -; -; 30; 2180; S; 25, 33) -; -; 85; 2180; S; 15 -36) 50; 10; 90; 2116; 30 - 37) 65; -; 60; 2105; E; 30. 
Table 1: The differentiation of grasslands and woods in the intermontane basins of North Osetia-Alania. Legend: tree layer ( $\mathrm{t}$ ), shrub layer (s) and herb layer (h); groups: subalpine birch elfin woods and pine forests (w), subalpine meadows (m), meadowsteppe communities (s). Locality, coverage of the layers, altitude, slope aspect and inclination are submitted in the appendix.

Tabela 1: Razlike v traviščih in gozdovih v visokogorskih kotlinah severne Osetije-Alanije. Legenda: drevesna plast ( $\mathrm{t}$ ), grmovna plast (s) in zeliščna plast (h); skupine: subalpinski pritlikavi brezovi sestoji in borovi gozdovi (w), subalpinski travniki (m), stepske travniške združbe (s). Lokacija, pokrovnost plasti, višina, ekspozicija in nagib so predstavljeni v dodatku.

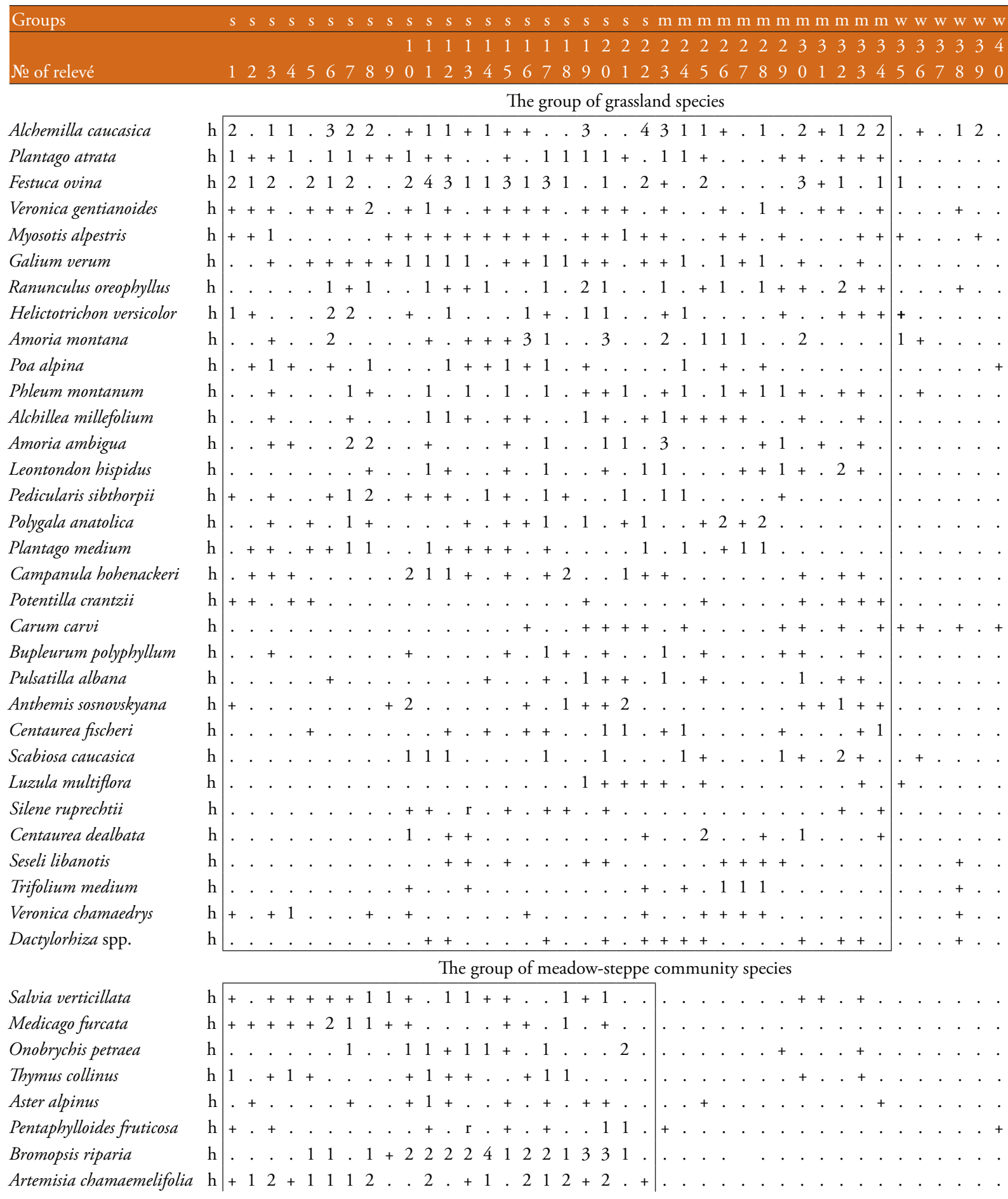




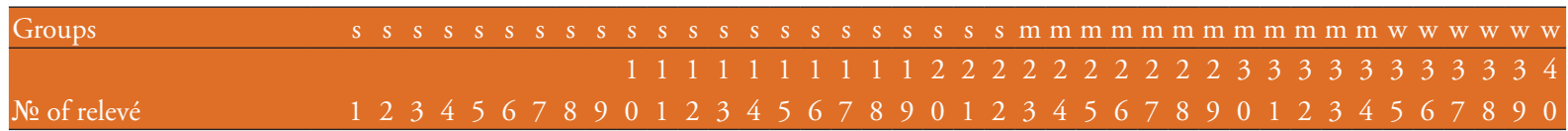

Artemisia marschalliana

Astragalus oreades

Veronica caucasica

Carex humilis

Linum nervosum

Koeleria cristata

Tephroseris caucasigena

Linum hypericifolia

Artemisia splendens

Onosma caucasica

Stipa pulcherrima

Festuca valesiaca

Bromopsis variegata

Lotus corniculatus

Trifolium canescens

Agrostis tenuis

Anthoxanthum odoratum

Tragopogon reticulatus

Rhinanthus minor

Geranium sanquineum

Stachys macrantha

Primula macrocalyx

Cruciata laevigata

Calamagrostis arundinacea $\mathrm{h}$

Nonea echioides

Astrantia maxima

Avenella flexuosa

Brachypodium sylvaticum

Betula litwinowii

Salix caprea

Pinus sylvestris

Sorbus aucuparia

Galium boreale

Viola canina

Primula ruprechtii

Ranunculus polyanthemos

Potentilla erecta

Fragaria vesca

Geranium sylvaticum

Vaccinium vitis-idaea

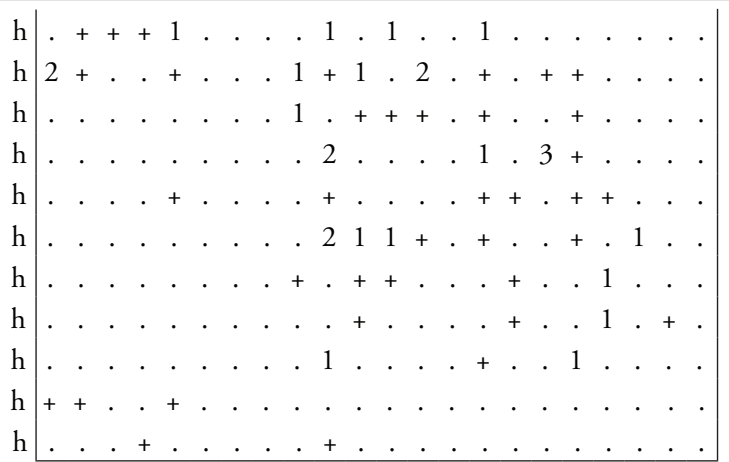

The group of subalpine meadow species

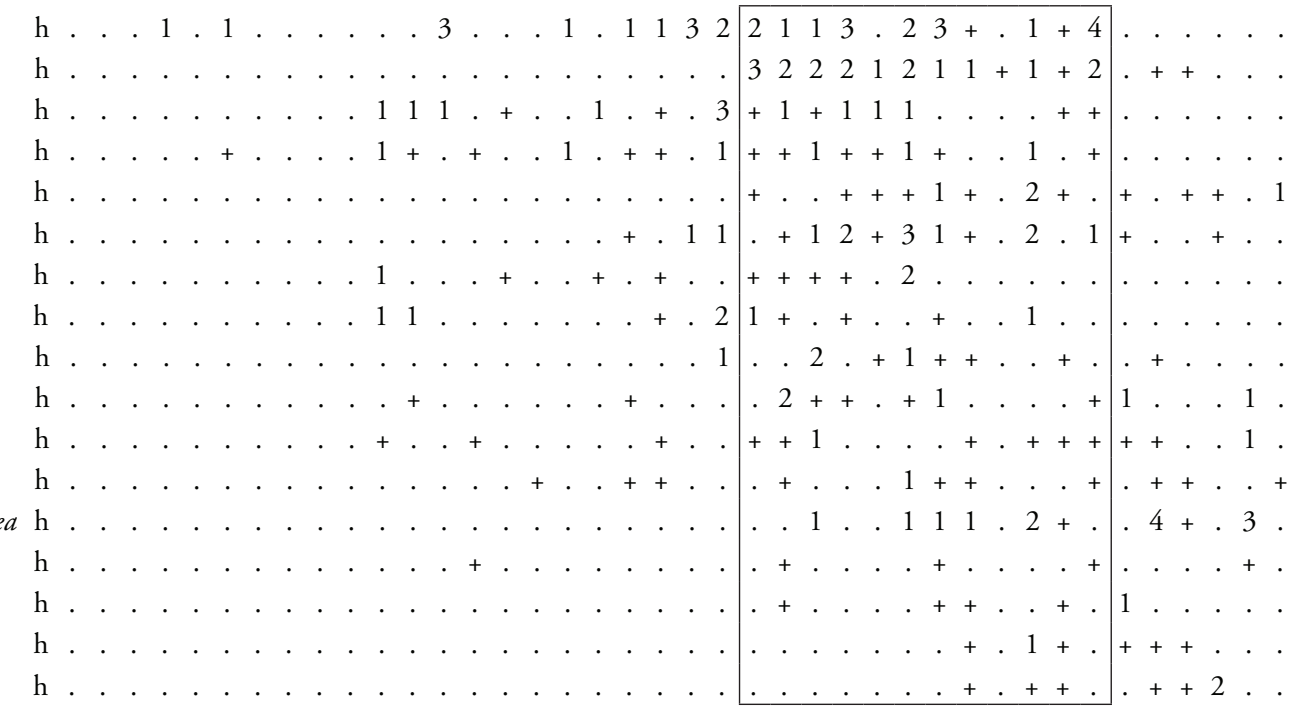

The group of forest community species

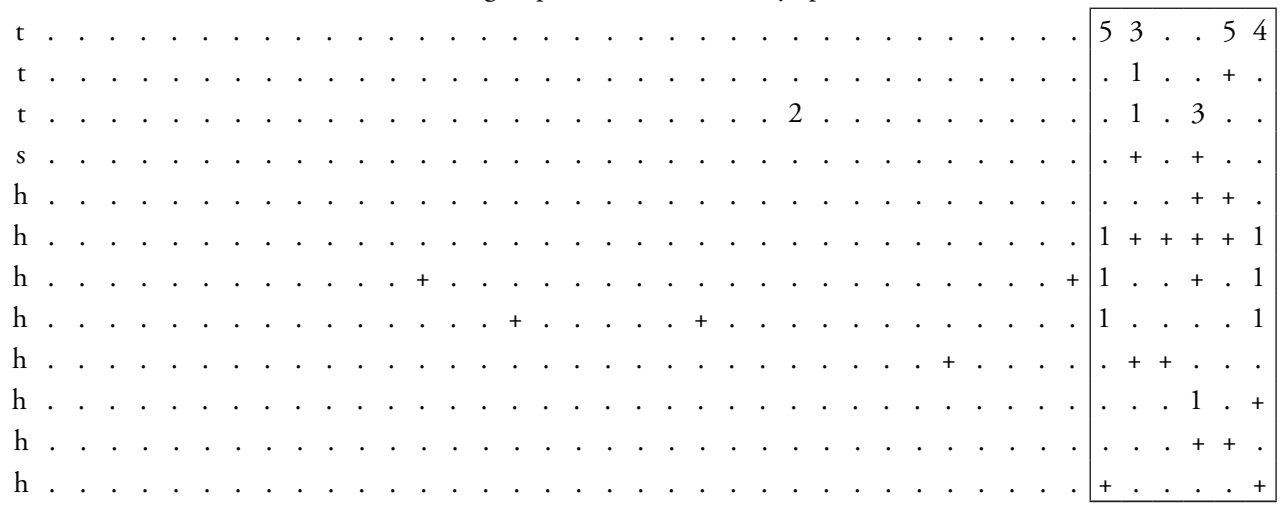

